\title{
Water Management in Post-colonial Darjeeling: The Promise and Limits of Decentralised Resource Provision
}

\section{Georgina Drew \& Roshan P. Rai}

To cite this article: Georgina Drew \& Roshan P. Rai (2016) Water Management in Post-colonial Darjeeling: The Promise and Limits of Decentralised Resource Provision, Asian Studies Review, 40:3, 321-339, DOI: $10.1080 / 10357823.2016 .1192580$

To link to this article: https://doi.org/10.1080/10357823.2016.1192580

曲 Published online: 24 Jul 2016.

Submit your article to this journal $\pi$

Џ Article views: 191

Q View related articles $\widetilde{ }$

View Crossmark data $\nearrow$ 


\title{
Water Management in Post-colonial Darjeeling: The Promise and Limits of Decentralised Resource Provision
}

\author{
Georgina Drew ${ }^{\mathrm{a}}$ and Roshan P. Rai ${ }^{\mathrm{b}}$

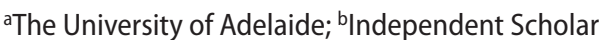

\begin{abstract}
Water crises are spreading across the length of South Asia at an alarming rate, and some of the pockets of stress include unexpected locations such as Darjeeling, West Bengal, where rainfall is plentiful. This article explores the problems of post-colonial water management in the former British hill station to illuminate the prospects for integrated resource provision. We argue that to improve the scope of water distribution and provision, post-colonial townships such as Darjeeling need to acknowledge and address the multiple ways in which people get water from the centralised supply as well as the decentralised solutions that have arisen through community organisation in collectives known as samaj. Notably, the samaj have a distinct character based on histories of colonial neglect that prompted villages throughout the Darjeeling region to solve socioeconomic problems independently of centralised systems. The discussion overlaps the numerous resource pathways with the plethora of social and political organisations operating in Darjeeling to argue that municipalities would do well to harness the varied ways in which water flows through the township. Integrated within larger questions of sustainable development in India's urbanising townships, the text offers a glimpse into the possibilities for more holistic and equitable water management.
\end{abstract}

\section{KEYWORDS}

Water management; postcolonial infrastructure; centralisation; decentralisation; community organisation; Darjeeling

\section{Introduction}

It is said that water "crises" are spreading across the length and breadth of South Asia and that the next conflicts over water could escalate into "water wars" if regional needs are not adequately met (Chellaney, 2013; Shiva, 2002). While it is true that water stress is growing in many locations, what is often left out of the picture is the high levels of water wastage that are all too common as well as the efforts at resource revitalisation and distribution that arise to ameliorate water struggles. The latter programs often involve community organisation and water resource decentralisation. The scope and effectiveness of these programs varies greatly depending on the hydrological, geographical and sociocultural particularities of the locations in which such efforts are focused. In this article, the nuances of resource 
management and collective organising in Darjeeling are explored to examine the problem of resource stress in one of India's burgeoning tourist hubs.

Darjeeling, a rapidly-growing township in the hills within West Bengal, is best known for its tea plantations, scenic vistas of lush mountainous terrain, and relatively cool summertime temperatures that provide a respite from the heat of the Indian plains. Despite its prominent natural endowments, including the location's high average rainfall and abundant springs, many might be surprised to find that fresh water is in short supply. In fact, regular access to water can be one of the most pressing resource challenges for Darjeeling residents and visitors. Exploring this problem, we sketch out the parameters and power dynamics of distinct paradigms of water resource management in present-day Darjeeling while being critical of colonial and contemporary approaches to acknowledge and ameliorate its scarcity. By outlining the water politics in a well-known hill station, and the persistent trend towards resource externalisation, our aim is to flag the outdated resource models and mindsets in play and to highlight the need for more integrated approaches to address current and future resource inequities. We argue that to fully understand the remedies for the dire state of water access, greater resource internalisation, social inclusion and public participation are critical.

At issue in the exploration of Darjeeling's water woes is the tension between centralised and decentralised resource management approaches. On the one hand, Darjeeling has a functional water supply system that has lasted more than 80 years. On the other hand, many people are left out of this distribution system and are forced to fend for themselves. This has resulted in the growing number of village collectives that self-organise to access and manage water. These community groups, known as gaon samaj (henceforth samaj) have historically focused on issues of communal welfare but most recently have instituted various solutions to tackle the lack of connection to municipal water supplies. While their efforts are impressive and worthy of praise, ultimately these organisations are making up for the inability of the municipal infrastructure to provide all residents with equitable access to life's most vital resources. The examination that follows pits these two approaches centralised and decentralised - against each other to question the efficacy and longevity of the systems currently in place. If we take these two models as paradigms of development, with government-run systems on one side and community-run solutions on the other, it becomes possible to see ways in which these divisions can be bridged in a third approach that might allow for more integrated measures to address Darjeeling's water stress. As the article discusses, this approach involves recognition of the numerous water flows through Darjeeling along with an understanding of the social networks and economic and political practices that form around these flows. Included in this discussion is the issue of water quality and the need for access to safe, potable resources.

As a final preface to the arguments that follow, it bears noting that Darjeeling district and Darjeeling town are subjects of increasing academic attention. Many investigations look at Darjeeling's ethnic and linguistic diversity, as well as the tensions between plains-based and hill-based residents of West Bengal. The rights of indigenous groups and Nepali-speaking populations are included in these explorations (Chettri, 2013; Foning, 1987; Ganguly, 2005). Some assert that at issue in such tensions is the politics of belonging (Middleton, 2013). There is also an interest in how identity politics informs demands for autonomy and the creation of a proposed new federalist state (Bagchi, 2012). ${ }^{1}$ Recent studies have been particularly focused on labour issues in Darjeeling's numerous tea plantations, including gender dynamics and the inequities that persist even in the light of organic and fair trade production 
practices (Besky, 2008; 2014; Sen, 2012). Even as water rights run through many of these studies as a subtheme, however, little attention has focused on how water resources feature in Darjeeling's socioeconomic landscape and political context. It is important to highlight these connections, as others have argued that water can be a conduit and symbol of power (Donahue \& Johnston, 1998; Swyngedouw, 2004), that water scarcity is often manufactured (Johnston, 2005), and that many of India's water management approaches are unwisely demand-driven and inefficient, meriting critical investigation (Iyer, 2003).

In this article, we argue that the examination of water stress adds an important dimension to the study of both a hill station such as Darjeeling and the idiosyncrasies of water management in post-colonial urban spaces. This builds upon recent efforts to expand discussions of urbanisation to areas such as India's "middle towns" where important livelihood struggles are waged and where roughly 40 per cent of the population lives (Scrase et al., 2015, p. 217). Of particular interest in such examinations is the issue of the potential for sustainable urban development in locations such as Darjeeling, a focus that Mell and Sturzaker (2014) have pursued in ways that we discuss towards the end of this article. The significance of Darjeeling as an urbanising place of environmental and social significance was not lost on us as researchers. To our minds, Darjeeling is emblematic of the disconnect between resource desire and availability in many parts of an India undergoing expansion. It also points to the ongoing legacies of colonial resource management and the need to investigate the possibilities for more integrated measures to meet demands in the twenty-first century. While the first author's work is academic in nature and the second author's work is grounded in community-based participatory development, our experiences point to a consistent gap in the ways in which people connect to and demand resources, and how the Indian state goes about water provision.

The arguments that follow are based on a mixed set of methods. Since 2011, we have been collaborating on the study of water in Darjeeling for a previous project entitled "Everyday Religion and Sustainable Environments in the Himalaya", a 3-year effort funded by The New School in New York City and the Henry Luce Foundation. When that project ended, we continued our studies independently. Our renewed focus leaves aside temporarily the religious dimensions that influence individual resource management practices in order to examine the multiple layers of Darjeeling's micro water politics. In this work, we have met with officials of Darjeeling Municipality as well as community activists and a selection of leaders from Darjeeling's samaj. ${ }^{2}$ This has involved focus group discussions with multiple samaj representatives. We have also qualitatively mapped out the water transmission and distribution lines that stretch across the length of Darjeeling township to examine the ways in which people are connected to, or disconnected from, the municipal supplies. Our efforts additionally benefit from previous studies that quantitatively pinpoint the location of Darjeeling's numerous springs (Boer, 2011). These studies provide stepping stones for understanding the extent to which people in Darjeeling's samaj depend upon spring water and the efforts they make to maintain access to these vital water resources. Archival materials, historical documents, academic literature and Roshan P. Rai's decades of experience living in Darjeeling also add to the data set on which our article draws. 


\section{Centralised Water Management in Post-colonial Darjeeling}

Since water is associated with power, and because water works have been a vital cultural as well as engineering tool of the colonial project in India (Chapman \& Thompson, 1995; Drew, 2014; Gilmartin, 1994; Stone, 1984; Whitcombe, 1972), it is important to acknowledge the past and ongoing legacies of British rule in outposts such as Darjeeling. A discussion of Darjeeling's water infrastructure therefore requires a contextualisation of its colonial origins and subsequent growth processes.

Prior to the founding of Darjeeling town, what is now Darjeeling district was sporadically inhabited for centuries by Lepcha ethnic groups and Nepali-speaking residents who also laid claim to the landscape (Chettri, 2013; Golay, 2006). The current sociocultural dynamics were to a considerable degree influenced by British colonial settlement and development practices. In the early nineteenth century, and in 1835 in particular, the British presence grew in the region after the East India Company obtained the lease of "a small strip of country in the south of the Sikkim Himalaya for the purpose of a sanitarium and an outpost of strategical [sic] importance on the northern frontier of India" (O’Malley, 1907, pp. 340-341). Acting as agents of the leased land, colonists such as Dr Arthur Campbell and Lieutenant Robert Napier "set to work to fell the forest and lay the foundations of the hill station of Darjeeling" (ibid.). Dr Campbell, who later became the Superintendent of Darjeeling, was influential in establishing the experimental tea stations that ultimately flourished. The sanitarium nomenclature used above stressed the colonists' desire for a zone of recreation and recuperation that offered climatic reprieve from the high temperatures of the Indian plains. The town they set up was evidently attractive to others, as the population rose from 100 to around 10,000 during the period from 1839 to 1849 . O’Malley notes that many of those involved in this "immigration" were "natives of the surrounding country quick to avail themselves of the blessing of life" under the new administration of the East India Company (ibid., p. 341).

Darjeeling Municipality was founded soon after the development of the Darjeeling hill station. Established in 1850, it is one of the oldest municipalities in India. Little is known about the extent of the water management infrastructure in the initial years of the growth of Darjeeling town, but by 1910-30 plans were laid for a large-scale water supply system that is still in operation. The system originates below Senchel Wildlife Sanctuary, located 15 kilometres upstream of Darjeeling. At that location, two lakes were manufactured for the storage of 33 million gallons of water that is perennially recharged by 26 springs. ${ }^{3}$ Since it was implemented, the system operates on a gravity-based distribution in which water flows through a series of pipes through a filter house and two distribution tanks.

According to the municipality, the water supply system for Darjeeling town has around 35 kilometres of pipes for the transmission of water from Senchel lakes and 83 kilometres of pipes to distribute water within the township. A public report of the Darjeeling Waterworks Department (2012) notes that 95 per cent of the existing pipeline and valves were laid by 1930. This system is in great need of repair, revitalisation and improvement. As the report laments, no work at all was done in the past to replace the old pipeline or leaking valves. The authors add that most of the repair and restoration of the system has only been taken up on an "ad-hoc basis" and that this is why water leaks can be noticed in so many parts of town (ibid.). 
This supply of water from Senchel lakes was originally meant to support a population of around 10,000 people but the population of permanent residents in Darjeeling currently includes just over 120,000 people, according to the Government of India's 2011 census. The transitory population, including students, tourists and migrant workers, can add between 200,000 and 300,000 seasonal residents. With an outdated and inefficient water supply system, many lower-income and middle-class households struggle to secure adequate resources for their day-to-day operations. The Darjeeling Waterworks Department (2012) attests to this when stating that the water deficit in Darjeeling is around 1.33 million gallons per day. Those with relatively more money, however, are able to secure household-specific pipelines or to buy into piped supplies that are distributed within select neighbourhoods. The result is that, as one walks through Darjeeling, one sees bundles of several dozen pipes. The water these pipes carry can come from the main distribution line or from tapping into Darjeeling's springs.

At other points in the township, it is even possible to see water pipes strung above the ground at the same level as electrical cables. These pipes demonstrate the catch-as-catch-can nature of water supply in the town and are visual reminders of the diverse water networks

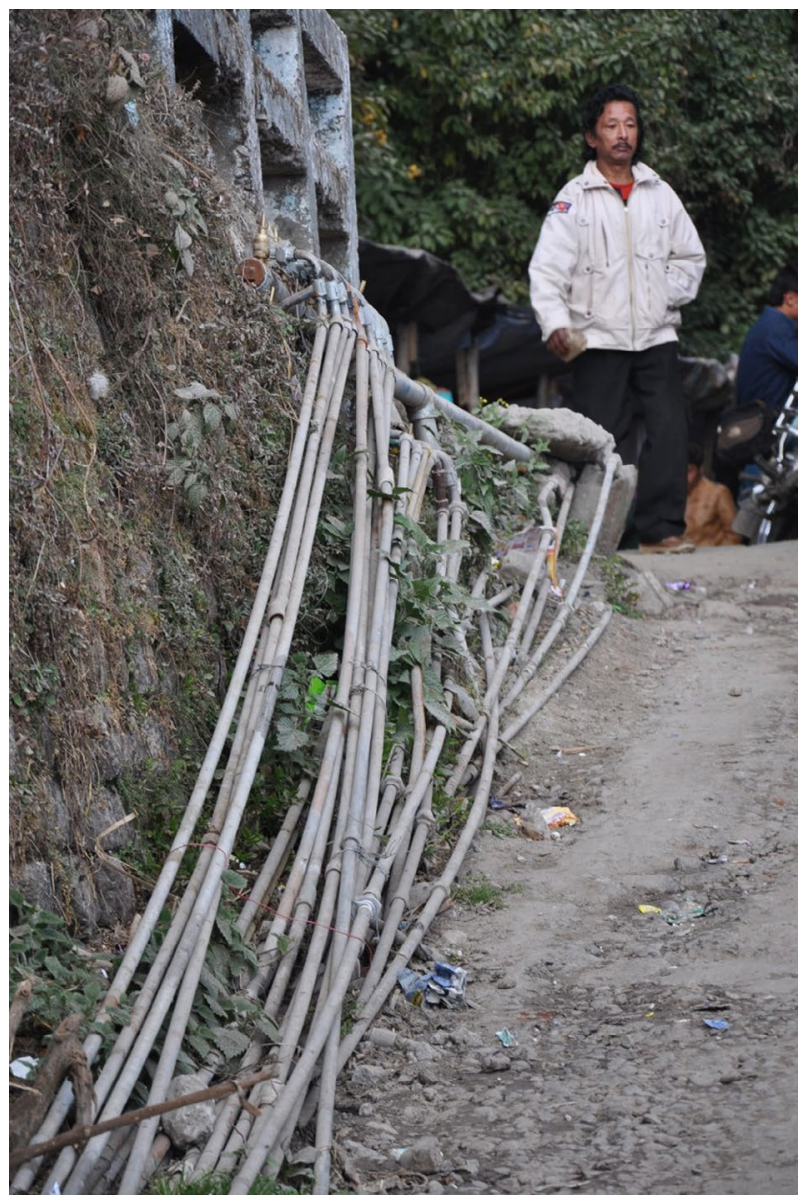

Figure 1. Pipes in Darjeeling's Main Market. Photo by Georgina Drew, January 2014. 


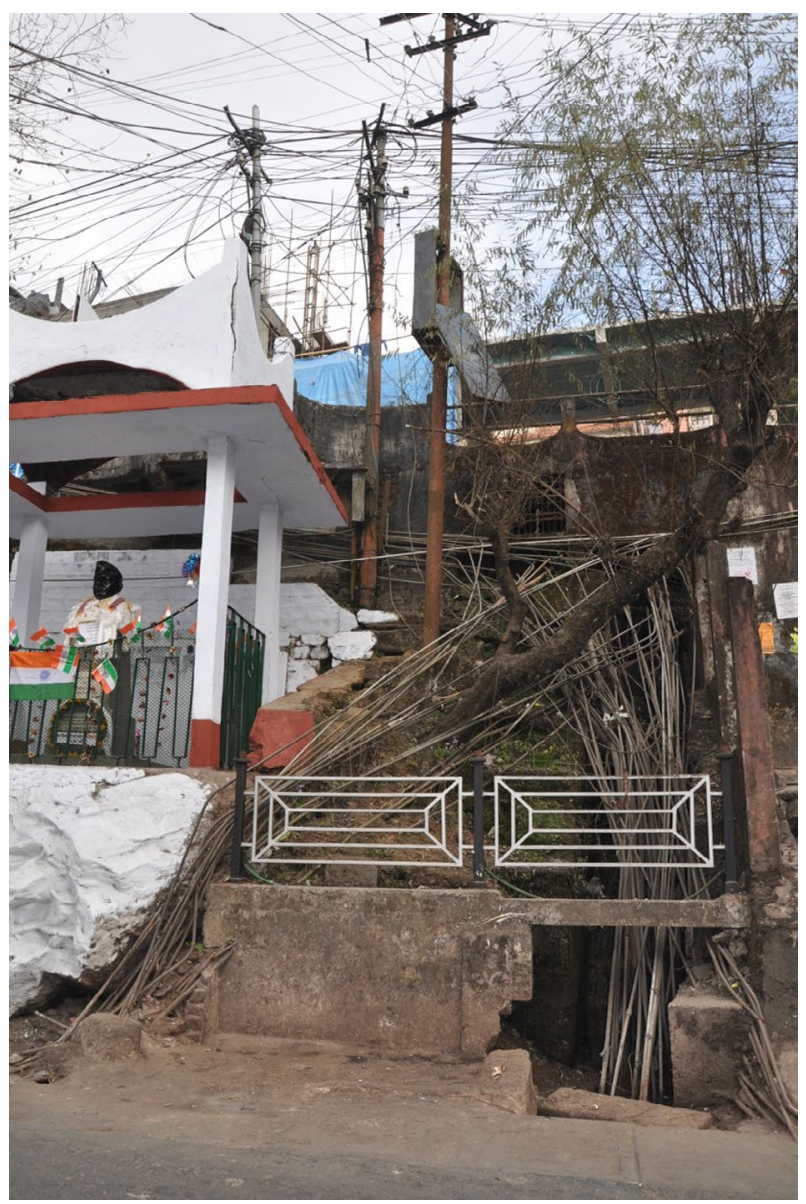

Figure 2. Pipes in Darjeeling's Main Market. Photo by Georgina Drew, January 2014.

and assemblages. They also stand as clear evidence of the substantial rates of water loss through leakage, as these pipes regularly drip water onto passers-by below. At an aggregate, the estimates of total water loss are staggering. According to a water engineer at the Waterworks Department interviewed in early 2014, the loss of water in transmission from Senchel lakes to the township is around 30-35 per cent of the water supplied. The employee commented that about as much again could be lost within the distribution main. This means that another 30-35 per cent of the water supply could be lost after a mere 65-70 per cent of the town's water capacity reaches the distribution centre.

Given the average $3,092 \mathrm{~mm}$ of rainfall per year recorded by the municipality of Darjeeling, ${ }^{4}$ one might imagine that the town receives ample water to make up for the leakages in the distribution system. The rainfall is mostly concentrated in the monsoon months of May to September when the deluge flows quickly down the steep slopes of the Darjeeling hills. While most of this is lost, some precipitation infiltrates the system to emerge as springs, which become the source of water for the rest of the year. The high quantum of precipitation sits oddly within the everyday lived realities and prominent discourses, which revolve around the notion of Darjeeling's "water crisis". Evidence of this is a common 
notice at all hotels alerting tourists that "There is acute water scarcity in Darjeeling. Kindly use water sparingly!" The seeming oxymoron of leaking pipes and water shortage despite the high annual quantum of rain is a popular point of conversation among residents and visitors alike.

Concerns over water quality are also not insignificant. While access to water alone is a challenge in contemporary Darjeeling, it is even more difficult to obtain a potable water supply. The lack of safe drinking water and sanitation services adds to the public health concerns in Darjeeling. These can amplify seasonally such as during the summer tourist season (Mell \& Sturzaker, 2014, p. 75, p. 78). In addition to the unsafe biological matter that enters degraded and unkept pipes, Darjeeling's piped and spring water supplies are subject to cross-contamination from the runoff of 30 to 45 metric tonnes of solid waste that is generated in Darjeeling Municipality each day (Rai, 2011).

Exposure to untreated water increases the risks of contracting stomach ailments, which among school aged children can lead to educational setbacks if regular and untreated. It can also lead to more serious bacterial infections such as typhoid. The illness is caused when Salmonella enterica is transmitted through water or food contaminated with fecal matter. In 2003, typhoid was the third most common reportable disease in the district of Darjeeling, as less than 50 per cent of the district had access to potable water and sanitation in that year (Sharma et al., 2009, p. 697). Such studies indicate that the consumption of raw vegetables, unwashed fruit and contaminated dairy products was significantly associated with the cases of typhoid in Darjeeling district. Socioeconomic standing also influenced the incidence of illness, as low monthly income was associated with typhoid contraction. Sharma et al. explain: "Low family income is often related to poor level of education, poor housing, and living in unsanitary conditions without adequate water supply" (ibid., p. 700). Since the use of latrines can reduce the risk of disease, they argue for the use of closed sewage systems.

The call for closed and contained sewage flows is significant due to the concern for leakage into existing water supplies. This is especially important in light of residents' reliance on the spring water sources spread across Darjeeling. As noted earlier, numerous springs are found across the landscape of Darjeeling town and the surrounding areas. The exact number of springs is still under investigation. One report notes that there are 32 perennial springs (Boer, 2011) but more recent and in-progress studies argue that the number could be higher than 90 . In the past, these springs were linked to cultural and religious practices important to many of Darjeeling's ethnic groups. With the rise of urbanisation, the profile of these springs and spring usage is changing. Through the process of commodification, some springs have been cordoned off for a limited number of users, many of whom are not on the municipal water supply grid. ${ }^{5}$

Another aspect of the complication, and commodification, of Darjeeling's fluid mosaic (Moench et al., 2003) is the proliferation of private water distribution, wherein water is sold in small, non-piped units by people who supply water by the litre on handcarts or via water tankers. These provisions are supplementary to the centralised supply and provide a service in the absence of adequate municipal water resources. This latter category, being a market response to a need, also sits within a decentralised approach to water supply management in Darjeeling.

In the next section, we outline these privatised responses as well as the community-managed solutions that are prominent among Darjeeling's samaj. 


\section{Decentralised Water Management and Samaj-led Initiatives}

Though significantly different in motivation and approach, we propose to consider the per-litre and for-profit distribution system and the work of gaon samaj to collectively organise for water access as both falling within decentralised responses to Darjeeling's resource challenges. We first consider the privatised water distribution network before looking at the community-managed not-for-profit options.

Given the low amount of water that reaches most households each week through the piped municipal water supply, and due to the low quality of some of this water, more and more of Darjeeling's residents have begun to pay for water distributed by the litre. There are numerous systems in place to accommodate this market. Some of the distribution is very small scale with enterprising individuals selling water that they have sourced from nearby springs and streams in gallon jugs. ${ }^{6}$ Others sell water that they distribute via handcarts in larger quantities to households. A more popular option, since it supplies the largest quantity of water per purchase, is the tank water distribution system.

It is a common daily sight to see tank or "tanker" water being ferried across Darjeeling and the greater municipality in large trucks. Bumping along pot-holed roads in truckbeds, the 500-6,000 litre tanks lurch back and forth, spilling out water across the pavement. Much of this water is sourced from collection points near and around the Senchel Wildlife Sanctuary or from spring sources even further afield. Inefficient though it is, the tank water suppliers find no shortage of takers for their product. While the price is high, around 1,0001,500 INR (18-27 USD) per 6,000 litres, many residents are willing to pay a premium to ensure they have the minimum household requirements for bathing, cooking and cleaning.

Informally, residents are apt to refer to the tanker system as a "water mafia". There is little veracity to this claim - their operations are perfectly legal - but what in effect they are referring to is the small number of players at the top of the business model and the growing sense that a monopoly is emerging. With the market cornered, and with demand continuing to grow amidst dwindling water supplies, there is always the possibility that the management could increase the prices substantially. Given the low average wages in Darjeeling, this could put tanker water out of the reach of some of its current beneficiaries. It could also mean that, for those who pay, even more of the household finances could go towards accessing a vital necessity.

There are, of course, people who cannot pay for tanker water on a regular basis. Many of these are Darjeeling's lower-income residents who live within and just outside the town's bustling centre. Nestled predominantly along the sloping hillside, many of these residents are grouped into small clusters. Some but not all have self-clustered along ethnic and religious lines. These groups in many cases are part of the aforementioned community-based organisations known as samaj. In the remainder of this section, we present the samaj as a vital component of the social network that intersects with water flows.

The samaj have a long and admirable history in the Darjeeling hills. Originally created to provide basic support and welfare services, they offer a vital safety net for members. By taking monthly fees, often of around 100 INR (2 USD) per member, the samaj have a pool of resources to distribute in times of need such as medical emergencies, weddings, funerals and disasters. When needed, these funds are disbursed as one-off grants or as loans. Additional funds can also be collected depending on the situation and the particularities of the samaj. In some samaj, for instance, each member is likely to give an additional 20-50 
INR (0.5-1 USD) to a family that has experienced a trauma such as a medical emergency or a death. When pooled, these funds help to cover medical fees and the high costs that can be associated with funerals. The result is that, despite the cost of membership, samaj beneficiaries feel strongly that they are a vital feature of Darjeeling's social organisation.

A driving concept of the samaj is the idea that they provide kalyan, a Nepali term that can be translated as "welfare". When samaj leaders were asked why people join the collectives, one respondent replied using this English translation, stating that the motivation was to receive "welfare". He added that the samaj are akin to an insurance system that simultaneously provides and promotes "self-reliance". As another member adamantly stated, the samaj ultimately offer an "invisible structure" that provides a buffer to the risks and insecurities associated with everyday life. The respondent, a woman in her late 50s who was also a samaj leader, also commented that her involvement in the collective gives her a sense of fulfilment at a time in her life when she otherwise might have experienced depression and a loss of purpose. Reflecting on this, she stated that the "samaj need people and people need samaj". Others agreed, stating that life without the support of the samaj would be difficult.

Increasingly, samaj are focusing on water provision for their members. Since water is a basic necessity, the efforts to acquire and ensure equitable water resources are a natural extension of the samaj emphasis on augmenting member welfare. Given the varied socioeconomic backgrounds and geographical/topological contexts of Darjeeling's numerous samaj, the solutions that these collectives pursue to offset or ameliorate water stress can vary greatly. Some samaj choose to build new tanks to store water; some samaj restore, repair or maintain nearby springs; some samaj pool resources to acquire tanker water; and some samaj opt to lobby the municipality for access to piped water supplies. There are instances in which a variety of these options are pursued.

The Muldara samaj is an example of mixed approaches to addressing residents' water woes. Samaj representatives commented that the area around their village is "like a desert" for up to eight or nine months a year even though it is just a stone's throw down the hill from Darjeeling market's main gathering space, known as Chowrasta. Since they are not on the municipal supply lines, residents have to walk further down the hill to the closest spring. At the spring, they must queue for water before making the return trek back up, a process that can take one and a half hours each time. Even though the samaj also buys water to fill a tank in the village, the water is insufficient and the prices are too high for the collective to make regular purchases. Their proposed solution to this problem, when asked, was for more municipal assistance and perhaps a municipality-funded project to build more water storage tanks in the village. The question of how they would get these tanks filled remained, however, leaving little indication of a long-term solution.

Given the lack of affordable water sources, and as evidenced in the above examples, Darjeeling's springs remain important for the water access of many residents. Because a large number of springs dot the landscape around the town, these water sources provide a non-centralised distribution system that many samaj are able to utilise. A variety of factors, however, impact the quantity and quality of the spring water. Planned and unplanned development activities can alter the flow. The springs are also subject to seasonal and annual fluctuations based on weather patterns, precipitation factors and varying degrees of spring recharge. It is often up to the samaj to manage these springs, as their care falls outside municipality responsibilities. Thus, the springs are maintained according to informal non-government rules, set by the different samaj. "As a consequence," notes someone who studied 
32 of Darjeeling's springs, "local management as well as the condition of the springs differs significantly” (Boer, 2011, p. 7).

A case in point is the Mangalpuri samaj and its efforts to supply water to residents via a spring and a nearby pump house. Located downhill from the main road on the southeast side of Darjeeling township, Mangalpuri is a good example of samaj self-organisation in action. ${ }^{7}$ In light of the large number of hours that residents, and women and children in particular, were spending to access water from the spring source located even further downhill, the samaj decided to upgrade the supply service. It acquired a small parcel of land near the spring, where it built a tank that holds 8,000 litres. The land, which was generously donated by a resident, also boasts a small Hindu temple where villagers can worship when collecting water supplies. They no longer need to go every day, however, because the samaj set up a pumping system that is operated by two people who earn a monthly wage. Their fees, along with supplementary costs, are paid from the monthly member contributions. Since there is not always enough water to go around to each household daily, members can expect to receive water on alternate days to one of 22 distribution points located near their homes.

The leader of the Mangalpuri samaj was clearly proud of his collective's achievements in improving water access. He noted, however, that many more problems persist. The road down to the springs is poor, for instance, and there are problems of waste management and drainage. The most visible sign of this is the stream filled with noxious sewage and residential waste that flows next to their spring and the new pump house. While they had successfully solved their more pressing water problems, in other words, the case of Mangalpuri indicates the limits of what samaj can do in the absence of municipal support.

According to a representative of one of the most prominent environmental organisations in the Darjeeling hills, the struggles of the town's residents and samaj members illustrate effective community action as well as the unequal distribution of meagre resources. Since people are working independently via a decentralised system to meet their daily needs, moreover, there is a disproportionate burden and cost that is transferred to the urban poor. This cost involves time and energy as well as money. Because of the high level of effort, there are already signs that the samaj are beginning to exclude non-members from accessing the water resources they manage. It thus appears that the decentralised samaj response to water management has the potential to overlap with privatised rationales. Whereas before there were many common taps for public use, many of those are now gone. Since people are beginning to refuse others access to something that used to be seen as a common resource, he argued that there is evidence of a shift from public to private. Overall, it appears that there is a general trend towards the expansion of resource enclosures and exclusions, whether by the municipality or the samaj.

Another issue that gives one pause when praising the samaj is that there is an overall sense of pragmatism in their work. Samaj members were among the first to point this out. Recall, for instance, that they began in response to a need for greater social support and financial assistance that neither the colonial nor the post-colonial governments provided, and that their efforts on water similarly arose because water is a basic necessity that in many cases the municipality does not provide in sufficent quantities. Whereas to a casual observer it might seem that their water-focused efforts reflect a sense of environmental awareness, many members pointed out that this was not the case. The samaj leaders we spoke to, for instance, were generally aware of the need to address environmental challenges, but they stated that other members often did not share this concern. This comes out most clearly 
when the issue of waste is raised. While it is relatively easy to convince members to work on water storage and access issues, it can be difficult to get them to reduce their waste or to clean up polluted areas because, as one samaj leader put it, "waste is someone else's problem". Or, as another leader commented, "Environment comes later, society comes first". These comments are not particularly surprising, because even though many people can see the effects of environmental degradation, livelihood concerns can be of primary importance (Agarwal, 1994; Martinez-Alier, 2002).

The difficulty of mobilising people to create an integrated approach further reveals that the ability of the samaj to address both basic necessities and environmental problems is limited. In our formulation, an improved approach would involve tackling multiple resource concerns simultaneously while enhancing the coordination between different samaj. This latter point is particularly important. The samaj mostly work independently of one another and do not often share their knowledge and resources to tackle shared problems. Thus, the learning and success of one samaj does not necessarily translate to improved outcomes in other samaj to the extent that it could.

These efficacy concerns highlight the weak links in the decentralised approach. These observations push back against some of the praise that decentralised approaches to resource management in India have attracted (Agrawal, 2005; Mishra, 2001). At issue, given the post-colonial context, is also the larger question of civic opportunities versus governmental responsibilities. In other words, is it up to the samaj to promote integrated approaches to Darjeeling's environmental challenges? We suggest that the weight of sound resource management should not be on the samaj alone. Rather, we argue that greater public and municipal involvement is required to build a robust and integrated response.

Yet, even with their limited scope of impact, the samaj's activities can make a meaningful change in the quality of everyday life. In contrast to the system instituted at the Muldara location, Joshi (2014) shares accounts of the suffering of other lower-income residents who do not benefit from samaj efforts. She cites the case of Muskan Rai, a male college student and resident of Darjeeling town, to underscore the difficulties that some experience. Waking up early in the morning to go to the spring, Muskan Rai is forced to wait his turn in a long line of people with jerry cans, just to fill his can with 80-100 litres for the day. If the line is particularly long, he is late for school. To avoid this, he states "Sometimes I would go around $6 \mathrm{pm}$ after school in the evening to fill the water and get back home around midnight" (Joshi, 2014, p. 250; original emphasis). The author also states that at times of significant water scarcity, one needs to get up at around 3am in order to obtain undisputed water access, "or else one may spend hours waiting in line to fetch water" (ibid., p. 249). In our conversations with people collecting water at Jowahar Busty in Darjeeling, we heard similar comments and complaints from students, who lamented that their constant quest for water supplies reduced the amount of time they had to study.

The risk of not attending to more of the user experiences and struggles in Darjeeling is that those who go without water will continue to be relegated to the sidelines in a township that is already heavily marked by class inequalities, some of which fall across ethnic divisions (Ganguly-Scrase \& Scrase, 2015). Nikhil Anand's (2011; 2012) work on settler connections and disconnections with the municipal water supplies in one of Mumbai's bastis ("slums") reminds us of how the experience of everyday discrimination in water access can produce a sense of abjection. Providing commentary that is readily applicable to the Darjeeling context of minority ethnic and cultural marginalisation, he suggests that such abjection is a 
dialectical process wherein difference is constantly reproduced, enacted and foregrounded between people who have deep overlapping social histories. "Critically," he writes, "these differences are realised and reproduced through the production and management of urban infrastructure" (ibid., p. 490). Such remarks remind us to examine the scope of what some might term "hydraulic citizenship" 8 and the prospects for increasing social inclusion in the engineering and planning of South Asian urban ecologies (Baviskar \& Sundar, 2003; Rademacher, 2011).

\section{Water Management Options and Potential Solutions}

Before commenting on the possibilities for an integrated approach that could be coordinated between the multiple sectors of civil society and municipal or state governance, it is important to acknowledge the recent efforts that the Darjeeling Municipality has made to address resource stress. In light of the water resource access and distribution challenges, several plans have been put into various stages of development. These plans are being promoted after other measures, such as the attempt to build a third lake at Senchel, ${ }^{9}$ have failed.

One recent solution was to bring water up from the Balasun River, located in a valley downhill from Darjeeling. First conceived in 1995 and known as the Balasun River Project, the idea was to add one million gallons per day to the supplies in the two operational lakes at Senchel, located about 12 kilometres away. After Chief Minister Buddhadev Bhattacharjee laid the foundation in 2006, the system was briefly put into operation, but it was shut down after people complained about the quality of the water it provided. Since the Balasun River is located below many of the tea plantations as well as several rapidly-growing urban spaces, there were concerns that sewage and pesticides were contaminating the water. These suspicions were heightened when, during the first few days of the test run for the Balasun River Project, people complained that the supplies from Senchel appeared discoloured and unclean. The project's implementation was further hampered by geostrategic challenges, as some of the land earmarked for the laying of additional pipes ran through military complexes and there was difficulty in gaining clearance.

The efforts to augment the water supply, either by constructing new storage lakes or by diverting river water uphill to the two original lakes, exhibit several practical and conceptual shortcomings. Even if the third lake at Senchel or the Balasun River water extraction projects had worked, they would have put resources into the very same water system that is recognised as inefficient, wasteful and contaminated. Since the pipes that flow from the Senchel lakes are damaged and full of leaks, the projects in essence attempted to fill up faulty infrastructure. This is the equivalent of increasing the amount of water going into a leaking bucket rather than plugging the holes.

Recognising the flaws in the system, the government of West Bengal was persuaded by the Darjeeling Municipality to ensure funding of 170 Crore (1,700 million INR) to "revamp" the existing infrastructure. ${ }^{10}$ The idea is to fix the outdated pipes, including the transmission and supply lines. The project also entails the construction of 32 additional storage tanks, to be located in the 32 wards of Darjeeling. While this offers hope for improvement, the project nonetheless still props up the colonial-era water supply and distribution system. Moreover, the approach evidences a top-heavy centralised management system that predominantly addresses the water needs of the core of Darjeeling only. It fails to recognise that the town has rapidly grown beyond the 1930s core and that there are many more people living on 
the town's periphery who have the right to a water supply. Underlying these efforts is the hegemony of "common sense" evident in the promulgation of centralised systems of control and governance that Gramsci (1971) cautioned against.

Amidst these inadequate measures a larger question looms: How can the resource needs of centrally-located residents and those living on the outskirts be met at the same time? While there are several possible answers, it is clear that the myriad voices from the geographical and socioeconomic periphery need to be heard to augment post-independence spaces of participation and governance. There is much more work to be done towards this end, as the current municipal response does not adequately bring into the debates the multitude of samaj member views and experiences in the way that it could or should. This includes their knowledge and their experiences of successful decentralised water management and distribution. Without their integration, a vibrant community institution and resource is neither acknowledged nor fully supported. Whereas others have argued that to improve water management it is necessary to "let water appear" in the urban topography rather than relegating it to an underground abstraction (Dicks, 2014), we argue that it is equally important that the social networks and community efforts that intersect with water use also be made more visible in urban planning.

Similar to the way in which the samaj are overlooked, it seems idiosyncratic that many of the springs that populate Darjeeling are also ignored as possible solutions to water stress. This is even more curious given that a large proportion of the population depends upon the springs for their water needs. The springs are not only perennial sources of water but, being independent of the centralised supply, also provide one of the most reliable sources of water in Darjeeling. Yet, there are challenges in capturing and storing the spring water that the municipality could help to address. While some springs have been supplemented with tanks for water storage, this is not yet a common feature in Darjeeling. The municipality could help by supporting residential and samaj efforts to capture more of the springs in situ. This diversification of the resource base would mitigate the water shortages that occur when landslides and other disasters obstruct or damage the municipal pipelines. ${ }^{11}$ In the interim, a prerequisite for augmenting the role of Darjeeling's springs involves enhanced mapping of the catchment zone. Better data along these lines could help to identify springs that are in need of revitalisation and other landscape intervention possibilities. Of course, all efforts to use spring water would need to be accompanied by public awareness campaigns alerting residents to the need to boil or chlorinate spring water prior to consumption.

As is the case with the samaj that already exist within Darjeeling and whose impact could be augmented and amplified through coordination with the municipality, a number of readily available measures are in place that can be harnessed to diversify and expand the internalisation of Darjeeling's water resources. Many residents, for instance, are in the habit of collecting rainwater near their homes. This water is often collected from the runoff of rainwater into gutters and is used to flush toilets or water gardens. Some houses can collect as much as 100-3,500 litres of water during the rainy season. The problem with expanding the potential for household rainwater collection, however, is that many buildings have limited water storage facilities because land in Darjeeling is at a premium. Due to the ever-present risk of landslides and earthquakes, people are also hesitant to build permanent underground storage facilities that add weight to building structures and potentially compromise their stability. 
Despite the limitations on residential space for water storage, there are sizeable plots of land that could be used to collect water on a larger scale (Mell \& Sturzaker, 2014, p. 80). Notable landmarks include the palatial Governor's house and its sprawling grounds as well as the Darjeeling zoo. The military outposts currently use 50,000 gallons of Darjeeling's water supply per day (Darjeeling Waterworks Department, 2012) but, given the amount of land they occupy, there is scope to explore ways in which these outposts could be self-sufficient through rainwater harvesting and water conservation. If enough water is stored, it is possible that these rainwater harvesting and recharging measures could contribute to the supply of neighbouring areas.

These suggestions point towards the long-term plans that could be implemented. Even though the municipality complains of meagre resources for the kind of measures proposed, there is scope for the revision of taxation policies. Since families on the grid only pay 500 INR (9 USD) per year for domestic water supplies, and since people are also forced to purchase tanker water, it is possible that they would be amenable to paying more for their domestic supplies. Several people we spoke to, even those in under-served and lower-income areas, stated that they would be willing to pay more for improved municipal supplies. Such a measure would work if the rates were based on a careful pricing arrangement that took into consideration users' income capacities.

\section{Looking Forward: From Externalisation to Internalisation}

In setting up the two paradigms - centralised and decentralised - we in effect played with the overriding sense expressed by municipality officials and samaj leaders that these two domains overwhelmingly remain separate. This points to a lacuna, a gap, in the overall approach to Darjeeling's water challenges. These paradigms are not mutually exclusive, however, and could be integrated to a much greater degree. This would create more efficiency in water management and distribution. Such a change, we argue, would involve a transformation in the conceptual framework that is predominantly employed.

A key emphasis of this discussion has been on the need to augment access to safe, hygienic water supplies in Darjeeling in ways that are appropriate to the ecology, geography and cultural diversity of the township. Given the town's continual expansion (much of which has aesthetic implications for Darjeeling's heritage, as well as socioeconomic ramifications, according to Scrase et al., 2015), this focus means that questions of sustainability and sustainable development are also relevant. Yet, while we worry about the future generations whose welfare is underscored in the Bruntland Commission's (1987) vision of sustainable development, our understanding of sustainability in Darjeeling is also concerned with the immediate scarcities and challenges faced by contemporary residents. It is important to keep front-and-centre the fact that water challenges in Darjeeling are already urgent.

Darjeeling's sustainable development is a topic that Mell and Sturzaker (2014) discuss extensively in their examination of sustainable urban development in Darjeeling's "tightly constrained" geography. In their comments on the challenges, they assert that "sustainable development thinking argues for a more reflective approach to growth" (ibid., p. 68). It is for this reason that, when calling for alternative approaches to development in Darjeeling, they urge "a more dynamic, and more proactive, process of urban sustainable development" (ibid., p. 83). Chief among their recommendations is that there is a need to move from a top-down, "professional/investment-led" approach to planning and infrastructure 
provision towards a bottom-up "community-led" approach (ibid.). In agreement with Mell and Sturzaker, we assert that a change in approach is merited; we add that, in our formulation, it is one that should augment the internal social and resource capital to be found in Darjeeling.

Looking at the dominant water management trends, to rephrase the problem, the approaches that have been applied to date really only make sense if one's default is centralisation coupled with externalisation - the act of always drawing from outside or from "elsewhere" to meet resource needs. As many - including some of the world's leading environmental economists - have remarked, this tendency is what has driven many of the most large-scale components of ecological destruction and unsustainability (Daly, 1996, 2008; Meadows, Randers, \& Meadows, 2004). The inclination to draw from elsewhere for water needs has in particular made the expansion of some of the world's most famous cities and metropolises possible. If the goal is to enhance self-sufficiency and something akin to water sustainability, however, more internalisation is needed. We argue that a move towards increased internalisation is the key to promoting a truly integrated approach that maximises the opportunities afforded by the material and social features already in place.

The evidence indicates that, along with resource self-sufficiency, internalisation includes enhanced public debate, participation and coordination on resource challenges. This could involve creating more spaces for debate among Darjeeling residents, samaj members and the municipality. While we acknowledge that the samaj are not always equitable in their practices of inclusion, they nonetheless provide a built-in social network that could be tapped for information sharing and public engagement in policy. Since the samaj are limited in their ability to address environmental challenges that extend beyond the provision of basic needs, municipal collaborations could promote better waste management practices. The effective implementation of this would allow for more of the existing water resources to be used by people living in various parts of Darjeeling, as many sources are currently polluted and unfit for consumption.

The efforts towards increased inclusion and collaboration will be most effective if such processes simultaneously address gender, class and ethnic diversity. There is little evidence at present to indicate that either the samaj or the municipality fully integrates these diversities into their water management programs. While some, such as Joshi (2014) point to the need to address the diverse involvements of women in Darjeeling's micro water politics, and number of studies substantiate the gender-water connection in other parts of India (Ahmed, 2005; Feldhaus, 1995; Lahiri-Dutt, 2006), there is more room to expand this area of investigation and the potential for improving women's voices in policy decisions. Similarly, more work is needed to understand how the economically impoverished are faring amidst the seasonal shocks to the water supply. Since many of these inequities are felt spatially as well as socioeconomically, future studies would be well placed to qualitatively and quantitatively map the demographics of water access and stress in Darjeeling's steep topography.

The move towards resource internalisation and social inclusion would also enable civil society and the municipality to maximise existing resources while working to shape the assemblages that will continue to grow and be modified as more water connections, social networks and economic practices are advanced. The recognition and embracing of these entanglements is vital because the world's properties come into being only through relations of becoming that are not merely natural or cultural but intertwined in "multiplicity" (Deleuze \& Guattari, 1988). ${ }^{12}$ Engaging water at multiple levels of physical, social and 
geographic sites of connection could also help to develop more conversations about the values associated with such a vital resource and the ethics of its manipulation and distributional practices (Groenfeldt, 2013).

In short, the integration of Darjeeling's human and natural resources is vital to the goal of achieving potable water access as well as something akin to sustainable development in the township. As Lélé and Norgaard (1996, p. 335) argue, the answers to the driving questions of sustainability must involve an inextricable combination of value judgments, knowledges and worldviews that are relative to the institutions and social processes of the locations where they are enacted. In other words, both the parameters of sustainability and its potential enactments can and should vary depending upon the social and ecological landscapes in which the challenges are confronted. Such emphases are essential for improving potable water access in Darjeeling for current and future generations. If this is done properly, the township could provide a model for other locations in South Asia that are attempting to build upon outdated colonial infrastructures that often fail to provide basic resources to the people who are most in need.

\section{Notes}

1. In citing Romit Bagchi's 2012 publication, we also wish to note Rai's critical response to the book in a 2013 issue of Himalaya. The review notes that the book mostly draws from a section of the separatist movement rather than its entirety, and that the movement is portrayed by an author who does not believe in the activists' demands.

2. In all, we met with two municipal representatives, two technical water experts, two senior non-governmental organisation representatives, and fourteen samaj leaders. This amounts to a total of 20 key informants.

3. The lakes are designated as North and South. The North Lake, constructed in 1910, can hold up to 20 million gallons. The South Lake, constructed in 1932, can hold up to 13 million gallons.

4. Darjeeling, the Official Website of Darjeeling. Retrieved from http://darjeeling.gov.in

5. In the commodified spring supply arrangement, a person pays an entrepreneur an initial deposit for access to a spring on private land and thereafter pays a monthly fee for the water supply.

6. The term for these gallon jugs is either bhuldung or jerkin. The first word is of Nepali origin, whereas the second evidences a colonial influence. It is most likely derived from the expression "Jerry can", a container for liquids whose use was popularised in World War II.

7. Situated on the lower-most southeastern border of Darjeeling township, Mangalpuri bears the brunt of upstream waste dumping practices.

8. Hydraulic citizenship includes the distinctions made when particular citizens are recognised as worthy of receiving municipal water supplies while others, such as those living in informal settlements, are excluded.

9. In 1981, the Public Health Engineering Department attempted to add a third lake to the existing two lakes at Senchel that supply water to Darjeeling. It was intended to have a capacity of around 16.3 million gallons. Due to faulty construction, however, this lake is prone to leaks and is not in use.

10. The cost sharing is expected to involve $80 \%$ central government funds, $15 \%$ state funds, and 5\% municipal funds. See "RS 170 Cr Grants to Solve Hills Water Crisis", Times of India, 22 February 2014. Retrieved from http://timesofindia.indiatimes.com/city/kolkata/Rs-170crgrants-to-solve-Hills-water-crisis/articleshow/30814380.cms

11. There is a precedent for the role of springs in mitigating post-disaster water shortages. In 2012 in Gangtok (the capital of Sikkim, which has a similar population and mountainous topography to Darjeeling), spring water helped to provide for residential needs following a devastating earthquake that destroyed the town's infrastructure. 
12. Commenting on the nature of multiplicities, Deleuze and Guattari note: "Multiplicities are rhizomatic... A multiplicity has neither subject nor object, only determinations, magnitudes, and dimensions that cannot increase in number without the multiplicity changing in nature (the laws of combination therefore increase in number as the multiplicity grows)" (1988, p. 8). Our application of their work hinges on the idea that water must be treated as a material, sociocultural and socioeconomic set of assemblages that exist in ever-changing multiplicities.

\section{Acknowledgments}

Georgina Drew and Roshan P. Rai gratefully acknowledge the support of a Faculty Research Centre Competitive Funding Scheme Award from The University of Adelaide in 2014. Georgina Drew also acknowledges the receipt of ARC grant DE160101178.

\section{Disclosure Statement}

No potential conflict of interest was reported by the authors.

\section{References}

Agarwal, B. (1994). The gender and environment debate: Lessons from India. In L. Arizpe, M. P. Stone, \& D. C. Major (Eds.), Population and environment: Rethinking the debate (pp. 87-124). Boulder: Westview Press.

Agrawal, A. (2005). Environmentality: Community, intimate government, and the making of environmental subjects in Kumaon, India. Current Anthropology, 46(2), 161-190.

Ahmed, S. (Ed.). (2005). Flowing upstream: Empowering women through water management initiatives in India. Ahmedabad: Centre for Environment Education.

Anand, N. (2011). Pressure: The politechnics of water supply in Mumbai. Cultural Anthropology, 26(4), 542-564.

Anand, N. (2012). Municipal disconnect: On abject water and its urban infrastructures. Ethnography, 13, 487-509.

Bagchi, R. (2012). Gorkhaland: Crisis of statehood. New Delhi: Sage Publications India Pvt Ltd.

Baviskar, A., \& Sundar, N. (2003). Democracy versus economic transformation? Economic and Political Weekly, 43(46), 87-89.

Besky, S. (2008). Can a plantation be fair? Paradoxes and possibilities in fair trade Darjeeling tea certification. Anthropology of Work Review, XXIX, 1-9.

Besky, S. (2014). The labor of terroir and the terroir of labor: Geographical indication and Darjeeling tea plantations. Agriculture and Human Values, 31, 83-96.

Boer, L. (2011). Perennial springs of Darjeeling: A survey to community based conservation. Darjeeling: Ashoka Trust for Research in Ecology and the Environment.

Bruntland Commission. (1987). Our common future: Report of the World Commission on Environment and Development. Oxford: Oxford University Press.

Chapman, G. P., \& Thompson, M. (1995). Water and the quest for sustainable development in the Ganga valley. New York: Mansell.

Chellaney, B. (2013). Water, peace, and war: Confronting the global water crisis. New Delhi: Rowman \& Littlefield Publishers.

Chettri, M. (2013). Choosing the Gorkha: At the crossroads of class and ethnicity in the Darjeeling hills. Asian Ethnicity, 14(3), 293-308.

Daly, H. E. (1996). Beyond growth: The economics of sustainable development. Boston, MA: Beacon Press.

Daly, H. E. (2008). Growth and development: Critique of a credo. Population and Development Review, 34(3), 511-518. 
Darjeeling Waterworks Department. (2012). A report on water supply system of Darjeeling Municipal Area. Darjeeling, India: Darjeeling Municipality.

Deleuze, G., \& Guattari, F. (1988). A thousand plateaus: Capitalism and schizophrenia (Brian Massumi, Trans.). Minneapolis: University of Minnesota Press.

Dicks, H. (2014). A phenomenological approach to water in the city: Towards a policy of letting water appear. Environment and Planning D: Society and Space, 32, 417-432.

Donahue, J. M., \& Johnston, R. R. (Eds.). (1998). Water, culture, and power: Local struggles in a global context. Washington, DC: Island Press.

Drew, G. (2014). Transformation and resistance on the Upper Ganga: The case of British canal irrigation. South Asia: A Journal of South Asian Studies, 27(4), 670-683.

Feldhaus, A. (1995). Water and womanhood: Religious meanings of rivers in Maharashtra. New York: Oxford University Press.

Foning, A. R. (1987). Lepcha, my vanishing tribe. Kalimpong, West Bengal: Chyu-Pandi Farm.

Ganguly, R. (2005). Poverty, malgovernance and ethnopolitical mobilization: Gorkha nationalism and the Gorkhaland agitation in India. Nationalism and Ethnic Politics, 11, 467-502.

Ganguly-Scrase, R., \& Scrase, T. J. (2015). Darjeeling re-made: The cultural politics of charm and heritage. South Asia: A Journal of South Asian Studies, 38(2), 246-262.

Gilmartin, D. (1994). Scientific empire and imperial science: Colonialism and irrigation technology in the Indus basin. The Journal of Asian Studies, 53(4), 1127-1149.

Golay, B. (2006). Rethinking Gorkha identity: Outside the imperium of discourse, hegemony, and history. Peace and Democracy in South Asia, 2(1-2), 23-49.

Gramsci, A. (1971). Selections from the prison notebooks of Antonio Gramsci. New York: International Publishers.

Groenfeldt, D. (2013). Water ethics: A values approach to solving the water crisis. New York: Routledge. Iyer, R. R. (2003). Water: Perspectives, issues, concerns. New Delhi: Sage Publications.

Johnston, B. R. (2005). The commodification of water and the human dimensions of manufactured scarcity. In L. Whiteford \& S. Whiteford (Eds.), Globalization, water, and health: Resource management in times of scarcity (pp. 133-152). Santa Fe: School of American Research Advanced Seminar Series.

Joshi, D. (2014). Feminist solidarity? Women, water, and politics in the Darjeeling Himalaya. Mountain Research and Development, 34(3), 243-255.

Lahiri-Dutt, K. (Ed.). (2006). Fluid bonds: Views on gender and water. Kolkata: Stree Publishers.

Lélé, S., \& Norgaard, R. B. (1996). Sustainability and the scientist's burden. Conservation Biology, $10(2), 354-365$.

Martinez-Alier, J. (2002). The environmentalism of the poor: A study of ecological conflicts and valuation. Cheltenham, UK: Edward Elgar.

Meadows, D. H., Randers, J., \& Meadows, D. L. (2004). The limits to growth: The 30-year update. White River Junction, VT: Chelsea Green Pub.

Mell, I. C., \& Sturzaker, J. (2014). Sustainable urban development in tightly constrained areas: A case study of Darjeeling, India. International Journal of Urban Sustainable Development, 6(1), 65-88.

Middleton, T. (2013). Anxious belongings: Anxiety and the politics of belonging in subnationalist Darjeeling. American Anthropologist, 115(4), 608-621.

Mishra, A. (2001). The radiant raindrops of Rajasthan. New Delhi: Gandhi Peace Foundation.

Moench, M., Dixit, A., Janakarajan, S., Rahtore, M. S., \& Mudrakartha, S. (2003). The fluid mosaic: Water governance in the context of variability, uncertainty, and change. Kathmandu, Nepal \& Boulder, CO: Nepal Water Conservation Foundation \& Institute for Social and Environmental Transition.

O’Malley, L. S. S. (1907). Addendum II: Darjeeling and its mountain railway. In Bengal District Gazeteers: Darjeeling (pp. 321-458). New Delhi: Logos Press. Retrieved from http://darjeeling. gov.in/gazetteer/Appendum-II.pdf

Rademacher, A. (2011). Reigning the river: Urban ecologies and political transformation in Kathmandu. Durham: Duke University Press. 
Rai, R. P. (2011). Solid waste management in Darjeeling Municipality. In M. Desai (Ed.) \& S. Mitra (Co-ed.), Cloud stone and the mind: The people and environment of Darjeeling hill area (pp. 176180). New Delhi: K. P. Bagchi \& Company.

Rai, R. P. (2013). Gorkhaland: Crisis of statehood. Himalaya, 33(1\&2), 127-128.

Scrase, T. J., Rutten, M., Ganguly-Scrase, R., \& Brown, T. (2015). Beyond the metropolis - regional globalisation and town development in India: An introduction. South Asia: A Journal of South Asian Studies, 38(2), 216-229.

Sen, D. (2012). Illusive justice: The gendered labour politics of subnationalism in Darjeeling tea plantations. In S. Roy (Ed.), New South Asia feminisms: Paradoxes and possibilities (pp. 131-150). New York: Zed Books.

Sharma, P. K., Ramakrishnan, R., Hutin, Y., Manickam, P., \& Gupte, M. D. (2009). Risk factors for typhoid in Darjeeling, West Bengal, India: Evidence for practical action. Tropical Medicine and International Health, 14(6), 696-702.

Shiva, V. (2002). Water wars: Privatization, pollution, and profit. New Delhi: South End Press.

Stone, I. (1984). Canal irrigation in British India. New York: Cambridge University Press.

Swyngedouw, E. (2004). Social power and the urbanization of water: Flows of power. New York: Oxford University Press.

Whitcombe, E. (1972). Agrarian conditions in Northern India. Berkeley: University of California Press. 